\title{
MODEL PENGEMBANGAN KARIR DOSEN WANITA BERPERAN GANDA
}

\author{
Nurul Fitrianingrum \\ Universitas Islam Sultan Agung Semarang \\ fitrianingrum.nurul@yahoo.com
}

\begin{abstract}
The purpose of this study is to describe and analyze the effect on work motivation, family and social support dual role conflict to career development. Data were obtained from female lecturers Unissula Semarang using a questionnaire by 67 respondents. The sampling technique using non-random sampling method. Data analysis method used is multiple linear regression. The results of this study indicate that work motivation variable significant effect on career development, family support significant effect on career development, while the dual role conflict no significant effect on career development. Work motivation no significant effect on the conflict of roles, family support does not significantly influence conflict dual role. However, motivation and family support direct effect on career development.
\end{abstract}

Keywords: Motivation Work, Social Support Family, Dual Role Conflict, and Career Development.

\section{PENDAHULUAN}

Meningkatnya jumlah wanita bekerja diiringi pula dengan meningkatnya pendidikan wanita. Selain itu dengan majunya perekonomian saat ini memberikan peluang kepada wanita untuk bekerja secara professional. Semakin tinggi pendidikan yang dimiliki, dapat menunjang karir wanita untuk cepat memiliki pekerjaaan dengan jabatan yang bagusdan cemerlang (Handayani \& Salim, 2014). Undangundang Ketenagakerjaan Nomor 13 tahun 2003 pasal 156 memberikan kesempatan yang sama luasnya bagi pria dan wanita untuk menuntut ilmu, mengembangkan karir, dan memperoleh perlakuan yang tidak diskriminatif dapat terwujud secara optimal.

Fenomena yang terjadi saat ini adalah semakin banyaknya wanita yang bekerja secara professional diluar rumah. Motivasi yang mendorong wanita bekerja tidak hanya didorong oleh kebutuhan ekonomi keluarga, melainkan juga ada dorongan untuk mengaplikasikan keterampilan dan pengetahuan yang dimiliki, mengekspresikan diri di tengah-tengah keluarga dan masyarakat, mengembangkan potensi yang dimiliki dan juga untuk mencari eksistensi diri (Mangunwijaya dalam Setyowati dan Riyono, 2003). Namun keadaan wanita bekerja sangat bertolak belakang dengan keadilan yang semestinya didapatkan, karena masih banyak pekerja wanita yang merasakan tindak ketidakadilan ditempat kerjanya.

Berdasarkan latar belakang masalah diatas, maka penelitian ini akan menganalisis pengaruh motivasi kerja, dukungan sosial keluarga, dan konflik peran ganda terhadap pengembangan karir dosen wanita di UNISSULA Semarang. Penelitian ini dilakukan di kampus Universitas Islam Sultan Agung (UNISSULA) Semarang yang terletak di Jl. Raya Kaligawe KM. 4 Semarang, dengan objek penelitiannya yaitu dosen wanita di UNISSULA. Peneliti memilih objek tersebut karena peneliti tertarik pada terbukanya kesempatan berkarir untuk dosen wanita.Maka dari itu peneliti mencoba untuk melakukan 
penelitian mengenai tingkat pengembangan karir dari dosen wanita.

\section{KAJIAN PUSTAKA \\ Motivasi Kerja}

Walgito 2002 dalam Mustikallah (2013) motivasi adalah keinginan didalam seorang individu yang mendorong ia untuk bertindak. Motivasi juga dipengaruhi oleh faktor-faktor lain yaitu faktor internal yang terdiri dari sifat fisik, jenis kelamin, sifat kepribadian, intelegensia dan sifat bawaan.

Menurut Samsuddin

mendefinisikan motivasi kerja merupakan sesuatu yang menimbulkan dorongan atau semangat kerja.Motivasi juga dapat diartikan sebagai dorongan (driving force) dimaksudkan sebagai desakan yang alami untuk memuaskan dan memperahankan kehidupan.Sedangkan menurut Anoraga (2001) motivasi kerja merupakan faktor yang mempengaruhi manusia dalam bekerja.

Hasil studi yang dilakukan oleh Saman dan Meizara (2012) menunjukkan adanya pengaruh hubungan negatif antara motivasi kerja terhadap konflik peran ganda pada karir wanita.Artinya, bahwa wanita karir berhasil mengembangkan karirnya, terwujud dengan karir yang baik, meskipun terdapat peran ganda dalam dirinya sebagai ibu rumah tangga dan wanita karir.

$\mathrm{H} 1$ : Semakin tinggi motivasi kerja maka konflik peran ganda semakin rendah

Hasil studi yang dilakukan oleh Haryani (2013) menyatakan adanya hubungan yang positif antara motivasi kerja terhadap pengembangan karir. Artinya semakin tinggi motivasi kerja, maka pengembangan karir pun akan semakin meningkat. Hal ini terjadi karena sebuah motivasi kerja yang tinggi akan membawa pengaruh yang positif terhadap karir yang sedang dijalaninya dan dengan motivasi yang tinggi pula akan meningkatkan sebuah pengembangan karir ke arah yang lebih bagus.

H3: Semakin tinggi motivasi kerja maka pengembangan karir dosen wanita semakin meningkat.

\section{Dukungan Sosial Keluarga}

Menurut Saroson \& Smeth (1994) dalam Anggriani, dkk (2013) menyatakan bahwa dukungan sosial adalah transaksi interpersonal yang ditunjukkan dengan memberikan bantuan pada individu lain, dimana bantuan itu umumnya diperoleh dari orang yang berarti bagi individu yang bersangkutan.

Dukungan sosial keluarga merupakan merupakan faktor yang memiliki peranan penting untuk mencegah dari ancamam kesehatan mental (Amalia, 2007). Sedangkan dukungan suami merupakan dukungan yang secara tidak langsung sangat berpengaruh dan berperan penting bagi wanita karir dalam memelihara keadaan psikologis maupun fisiologis (Rustiana, 2006).

Hasil studi yang dilakukan Martika, Anggriana et al., (2015) menunjukkan pengaruh dukungan sosial keluarga terhadap konflik peran ganda bersifat negatif.Artinya semakin tinggi dukungan sosial keluarga, maka semakin rendah konflik peran ganda. Karena, dengan adanya dukungan dari orang terdekat (keluarga) menjadikan peran ganda seorang wanita dapat di minimalisir.

$\mathrm{H} 2$ : Semakin tinggi dukungan sosial keluarga maka konflik peran ganda semakin rendah.

\section{Konflik Peran Ganda}

MenurutNetemeyeretal. dalam Hennessy (2005) mendefinisikan Konflik peran ganda sebagai konflik yang muncul akibat tanggung jawab yang berhubungandengan pekerjaan mengganggu permintaan, waktu dan ketegangan dalam keluarga.Konflik peran ganda juga terjadi sebagai hasil dari kewajiban pekerjaan yang mengganggu kehidupan rumah tangga.

Menurut Kahn dalam Ummu (2011), mendefinisikan konflik peran ganda adalah bentuk dari inter-role-conflict dimana tekanan peran dari pekerjaan dan 


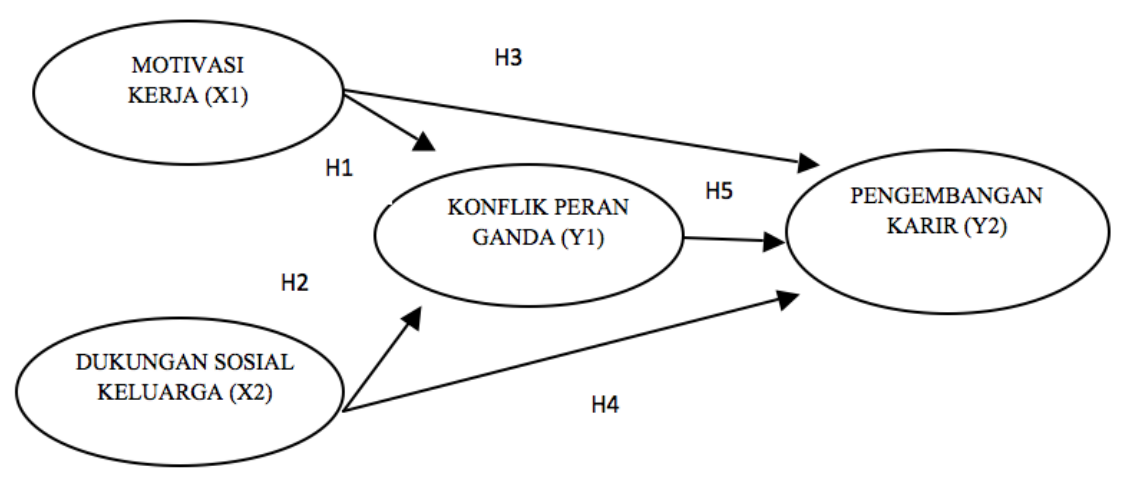

Gambar 1. Model Empirik Penelitian

lingkungan keluarga satu samalainsaling bertentangan.Konflik peran ganda juga merupakan konflik peran yang muncul antara harapan berbeda yang dimiliki oleh seseorang.Sementara menurut Khan dalam Hamid (2005) mendefinisikan bahwa konflik peran ganda merupakan peran seorang wanita sebagai wanita karir dan ibu rumah tangga yang merupakan tekanan peran dari pekerjaan dan lingkungan keluarga satu sama lain saling bertentangan.

Hasil studi yang dilakukan oleh Palupi (2009) menyatakan bahwa terdapat hubungan yang negatif antara konflik peran ganda terhadap pengembangan karir wanita. Artinya semakin konflik peran ganda tinggi, maka akan semakin rendahpengembangan karir. Dengan tingginya konflik peran ganda yang dijalani seorang wanita karir, maka secara otomatis akan menjadikan karir wanita tersebut menjadi rendah.

H5: Semakin tinggi konflik peran ganda maka pengembangan karir dosen wanita semakin rendah.

\section{Pengembangan Karir}

Karir adalah seluruh pekerjaan atau jabatan yang ditangani selama kehidupan kerja seseorang (Handoko, 2008). Wanita karir adalah wanita yang bekerja untuk mengembangkan kemampuannya. Wanita karir juga diartikan sebagai wanita berpendidikan tinggi dan mempunyai status tinggi dalam pekerjaannya yang berhasil dalam berkarya (Munandar, 2001).
Pengembangan karir adalah peningkatanpeningkatan pribadi yang dilakukan seseorang untuk mencapai suatu rencana karir (Handoko, 2008).

Menurut Kurnia (2001) dalam Nugroho (2009) pengembangan karir wanita merupakan orientasi karir yang dapat menyeimbangkan antara aktivitasnya dalam berperan sebagai seorang ibu dan seorang istri didalam keluarga dan berperan sebagai wanita professional ditempat kerja atau di lembaga/organisasi.

Menurut Munandar (2001) faktorfaktoryang mempengaruhi pengembangan karir bagi wanita adalah seperti: aktualisasi diri, motivasi, konflik peran ganda, rasa bersalah, berani sukses, dan pendidikan.

Hasil penelitian yang dilakukan oleh Virandra \& Alimatus (2014) menyatakan adanya pengaruh hubungan yang positif antara dukungan sosial keluarga terhadap pengembangan karir. Artinya semakin tinggi dukungan sosial keluarga, maka pengembangan karir akan semakin meningkat. Karena dengan adanya dukungan dari keluarga akan membuat karir dari seorang individu semakin berkembang karena merasa terdukung dalam menjalani tugasnya sebagai wanita karir.

Berdasarkan pendapat diatas, hipotesis yang diajukan dalam penelitian ini adalah sebagai berikut:

$\mathrm{H} 4$ : Semakin tinggi dukungan sosial keluarga maka pengembangan karir dosen wanitasemakin meningkat. 


\section{Model Empirik Penelitian}

Berdasarkan uraian tersebut diatas, maka model empirik yang dikembangkan dalam penelitian ini ada pada gambar 1 .

\section{METODE PENELITIAN}

Jenis penelitian yang dipakai dalam penelitian ini adalah penelitian explanatory research. Peneliti menggunakan beberapa metode dalam pengumpulan / pengambilan data: 1) Data Primer adalah data langsung dari objek penelitian. Data primer diambil dengan cara survey serta membagikan kuesioner kepada responden 2) Data Sekunder adalah data tidak langsung dari objek penelitian yang ada di Unissula. Data sekunder ini diambil dari studi pustaka, dan artikel internet yang berhubungan dengan penelitian ini. Responden penelitian ini adalah seluruh dosen wanita tetap yang bekerja di Unissula yang berjumlah 203 orang. Berdasarkan perhitungan penentuan jumlah responden yang menjadi sampel dalam penelitian ini menurut slovin (Umar, 2007) adalah 67 dosen wanita dari 12 fakultas di Unissula dengan kriteria dosen wanita masakerjanya sudah mencapai minimal 3 tahun dengan status pegawai tetap di Unissula. Metode penentuan sampel menggunakan non random sampling adalah teknik penentuan sampel dilakukan berdasarkan kemudahan saja tanpa memperhatikan strata yang ada dalam populasi itu.

\section{HASIL DAN PEMBAHASAN \\ Deskripsi Variabel}

Berdasarkan hasil penelitian dilapangan masing- masing deskripsi variabel adalah sebagai berikut:

\section{Motivasi Kerja}

Berdasarkan tanggapan 67 responden terhadap tiga indikator variabel motivasi kerja dapat dijelaskan bahwa lebih dari $50 \%$ responden menjawab setuju yang berarti responden memiliki motivasi kerja agar dapat lebih baik dalam bekerja guna untuk mengembangkan karirnya, dan hanya sedikit yang menjawab netral untuk kebutuhan prestasi dan kebutuhan afiliasi dalam motivasi kerja. Sehingga dapat disimpulkan bahwa motivasi kerja dosen wanita berperan ganda adalah sangat baik.

\section{Dukungan sosial Keluarga}

Berdasarkan tanggapan 67 responden terhadap empat indikator variabel dukungan sosial keluarga dapat diuraikan sebagai berikut:

Tanggapan responden yang dominan terhadap indikator dukungan emosional (DSK.1)sebesar62,7\% respondenmenjawab sangat setuju bahwa responden selalu mendapatkan kepedulian dari suaminya. Tanggapan responden mengenai indikator dukungan penghargaan (DSK.2) sebesar $59,7 \%$ responden menjawab setuju bahwa responden selalu mendapatkan dorongan untuk maju dari suaminya. Sedangkan tanggapan responden mengenai indikator dukungan instrumental (DSK.3) sebesar $47,8 \%$ responden menjawab netral dan tanggapan responden mengenai indikator dukungan informasi (DSK.4) sebesar $61,2 \%$ responden menjawab setuju bahwa responden selalu mendapatkan saran dari suaminya. Sehingga dapat disimpulkan bahwa dosen wanita berperan ganda banyak yang terbantu dan mendapatkan dukungan dari keluarga terutama dari suaminya.

\section{Konflik Peran Ganda}

Berdasarkan tanggapan 67 responden terhadap enam indikator konflik peran ganda dapat dijelaskan bahwa rata-rata responden menjawab sangat tidak setuju dan tidak setuju pada indikator peran ganda serta sebagian pula ada yang menjawab netral. Sehingga dapat disimpulkan bahwa sebagian besar dosen wanita berperan ganda di Unissula tidak merasa terlalu terbebani antara tugas kantor dan rumah tangga, meskipun sebagian merasa terbebani. Artinya, meskipun dosen wanita sibuk bekerja dikantor, tetapi urusan rumah 
Tabel 1. Hasil Uji Validitas Data

\begin{tabular}{|c|c|c|c|c|}
\hline Variabel & Indikator & r hitung & $r$ tabel & Keterangan \\
\hline \multirow{3}{*}{ Motivasi kerja } & Kebutuhan Prestasi & 0,646 & \multirow{3}{*}{0,242} & \multirow{3}{*}{ Valid } \\
\hline & Kebutuhan Afiliasi & 0,861 & & \\
\hline & Kebutuhan kekuasaan & 0,902 & & \\
\hline \multirow{4}{*}{$\begin{array}{l}\text { Dukungan sosial } \\
\text { keluarga }\end{array}$} & Dukungan emosional & 0,839 & \multirow{4}{*}{0,242} & \multirow{4}{*}{ Valid } \\
\hline & Dukungan penghargaan Dukungan & 0,928 & & \\
\hline & instrumental & 0,808 & & \\
\hline & Dukungan informasi. & 0,807 & & \\
\hline \multirow{7}{*}{$\begin{array}{l}\text { Konflik } \\
\text { ganda }\end{array}$} & Pengasuhan anak & 0,696 & \multirow{7}{*}{0,242} & \multirow{7}{*}{ Valid } \\
\hline & Bantuan pekerjaan rumah tangga & 0,723 & & \\
\hline & Komunikasi dan interaksi dengan & 0,771 & & \\
\hline & keluarga & & & \\
\hline & Waktu untuk keluarga & 0,740 & & \\
\hline & Menentukan prioritas & 0,643 & & \\
\hline & Tekanan karir dan keluarga & 0,628 & & \\
\hline \multirow{6}{*}{$\begin{array}{l}\text { Pengembangan } \\
\text { karir }\end{array}$} & Prestasi keria & 0,791 & \multirow{6}{*}{0,242} & \multirow{6}{*}{ Valid } \\
\hline & $\begin{array}{l}\text { Prestasl kerja } \\
\text { Exposure }\end{array}$ & 0,785 & & \\
\hline & $\begin{array}{l}\text { Exposure } \\
\text { Permintaan berhenti }\end{array}$ & 0,717 & & \\
\hline & $\begin{array}{l}\text { Permintaan berhenti } \\
\text { Kesetiaan pada organisasi }\end{array}$ & 0,744 & & \\
\hline & Mentor dan sponsor & & & \\
\hline & Kesempatan untuk berkembanng & $\begin{array}{l}0,732 \\
0760\end{array}$ & & \\
\hline
\end{tabular}

Sumber : Data primer yang diolah, 2016

Tabel 2. Hasil Uji Reliabilitas

\begin{tabular}{lll}
\hline Variabel & Cronbach's Alpha & Keterangan \\
\hline Motivasi Kerja & 0,829 & Reliabel \\
Dukungan Sosial Keluarga & 0,828 & Reliabel \\
Konflik Peran Ganda & 0,775 & Reliabel \\
Pengembangan Karir & 0,788 & Reliabel \\
\hline
\end{tabular}

Sumber: data primer yang diolah, 2016

tangga tetap dapat teratasi.

\section{Pengembangan karir}

Berdasarkan tanggapan 67 responden terhadap enam indikator pengembangan karir dapat dijelaskan bahwa lebih dari $50 \%$ responden setuju dalam bekerja telah mengimplementasikan variabel pengembangan karir dalam organisasi. Sehingga dapat simpulkan bahwa sebagian dosen wanita berperan ganda telah berhasil mengembangkan karirnya, meskipun ada sebagian terdapat tidak tertarik bahkan tidak setuju.

\section{Uji Validitas}

Uji validitas dalam penelitian ini digunakan untuk mengetahui apakah item indikator menggambarkan variabel. Perhitungan menggunakan SPSS versi 16. Apabila $r$ hitung > $r$ tabel (pada taraf signifikan $5 \%$ ), maka kuesioner tersebut valid. Apabila $r$ hitung $<r$ tabl (pada taraf signifikan 5\%), maka kuesioner tersebut tidak valid.

\section{Uji Reliabilitas}

Uji reliabilitas dalam penelitian ini digunakan untuk mengukur derajad konsistensi dan stabilitas data atau temuan, 
Tabel 3. PERHITUNGAN REGRESI BERGANDA

\begin{tabular}{|c|c|c|c|c|c|}
\hline Variabel terikat & $\begin{array}{l}\text { Variabel } \\
\text { bebas }\end{array}$ & B & $\begin{array}{l}T \\
\text { hitung }\end{array}$ & ß & Sign \\
\hline \multirow[t]{3}{*}{$\begin{array}{l}\text { Konflik } \\
\text { ganda }\end{array}$} & Constant & 11,100 & & & \\
\hline & $\begin{array}{l}\text { Motivasi } \\
\text { Kerja }\end{array}$ & $-0,071$ & $-0,287$ & $-0,037$ & 0,775 \\
\hline & $\begin{array}{l}\text { Dukungan } \\
\text { Sosial } \\
\text { Keluarga }\end{array}$ & 0,041 & 0,276 & 0,035 & 0,784 \\
\hline \multirow[t]{4}{*}{$\begin{array}{l}\text { Pengembangan } \\
\text { Karir }\end{array}$} & Constant & 5,697 & & & \\
\hline & $\begin{array}{l}\text { Motivasi } \\
\text { Kerja }\end{array}$ & 0,470 & 2,009 & 0,222 & 0,049 \\
\hline & $\begin{array}{l}\text { Dukungan } \\
\text { Sosial } \\
\text { Keluarga }\end{array}$ & 0,544 & 3,811 & 0,421 & 0,000 \\
\hline & $\begin{array}{l}\text { Konflik } \\
\text { Peran } \\
\text { Ganda }\end{array}$ & 0,026 & 0,216 & 0,023 & 0,829 \\
\hline
\end{tabular}

Sumber: data primer yang diolah, 2016

baik ditinjau dari waktu ke waktu maupun dari kondisi satu dengan kondisi yang lain. Perhitungan menggu nakan program SPSS versi 16 . Suatu kuesioner dinyatakan reliabel jika nilai cronbach alpha $>0,60$.

\section{Analisis Jalur (Path Analysis)}

Path analysis bertujuan untuk mengetahui pengaruh langsung maupun tidak langsung antara variabel bebas dengan variabel terikat. Dalam penelitian ini variabel intervening adalah konflik peran ganda diantara motivasi kerja dan dukungan sosial keluarga terhadap pengembangan karir.

Berdasarkan persamaan regresi linier berganda diatas dapat dijelaskan sebagai berikut:

$$
\begin{aligned}
& \text { Persamaan 1: } \\
& K P G=-0,037 M K+0,035 D S K+ \\
& \text { 0,023KPG +e }
\end{aligned}
$$

KPG (Konflik Peran Ganda),= -MK (Motivasi Kerja)+DSK (Dukungan Sosial Keluarga)+e (persen kelonggaran ketidaktelitian karena kesalahan pengambilan sampel yang masih dapat ditolerir).

\section{Persamaan 2: \\ $P K=+0,222 M K+0,421 D S K+0,023 K P G+e$}

PK (Pengembangan Karir) $=+$ MK (Motivasi Kerja)+DSK (Dukungan Sosial Keluarga)+KPG (konflik peran ganda)+e (persen kelonggaran ketidaktelitian karena kesalahan pengambilan sampel yang masih dapat ditolerir).

MK (motivasi kerja), DSK (dukungan sosial keluarga), dan KPG (konflik peran ganda) berpengaruh positif terhadap PK (pengembangan karir).

MK (motivasi kerja), DSK (dukungan sosial keluarga), dan KPG (konflik peran ganda) berpengaruh positif terhadap PK (pengembangan karir). 


\section{Pembahasan \\ Pengaruh Motivasi Kerja Terhadap \\ Konflik Peran Ganda}

Hasil pengujian yang dilakukan hipotesis pertama yaitu variabel motivasi kerja terhadap konflik peran ganda menghasilkan nilai $\mathrm{t}$ hitung sebesar $-0,287$ dengan nilai signifikansi sebesar 0,775 $(p<0,05)$. Maka dapat diartikan bahwa motivasi kerja berpengaruh negatif dan tidak signifikan terhadap konflik peran ganda. Arah koefisien regresi yang nagatif sebesar $-0,071$. Dengan demikian, hipotesis pertama dinyatakan ditolak yaitu tidak ada pengaruh signifikan antara motivasi kerja terhadap konflik peran ganda.

\section{Pengaruh Dukungan Sosial Keluarga Terhadap Konflik Peran Ganda}

Hasil pengujian yang dilakukan hipotesis kedua yaitu variabel dukungan sosial keluarga terhadap konflik peran ganda menghasilkan nilai $\mathrm{t}$ hitung sebesar 0,276 dengan nilai signifikansi sebesar 0,784 ( $p<$ $0,05)$. Maka dapat diartikan bahwa dukungan sosial keluarga berpengaruh negatif dan tidak signifikan terhadap konflik peran ganda. Arah koefisien regresi yang positif sebesar 0,035. Dengan demikian, hipotesis kedua dinyatakan ditolak yaitu tidak ada pengaruh signikan antara dukungan sosial keluarga terhadap konflik peran ganda.

\section{Pengaruh Motivasi Kerja Terhadap Pengembangan Karir}

Hasil pengujian yang dilakukan hipotesis ketiga yaitu variabel motivasi kerja terhadap pengembangan karir menghasilkan nilai t hitung sebesar 2,009 dengan nilai signifikansi sebesar 0,049 ( $p<0,05)$. Maka dapat diartikan bahwa motivasi kerja berpengaruh positif dan signifikan terhadap pengembangan karir. Arah koefisien regresi yang positifsebesar 0,222. Dengan demikian, hipotesis ketiga dinyatakan diterima yaitu ada pengaruh signifikan antara motivasi kerja terhadap pengembangan karir.

\section{Pengaruh Dukungan Sosial Keluarga Terhadap Pengembangan Karir}

Hasil pengujian yang dilakukan hipotesis keempat yaitu dukungan sosial keluarga terhadap pengembangan karirmenghasilkan nilai $\mathrm{t}$ hitung sebesar 3,811 dengan nilai signifikansi sebesar 0,000 ( $p<0,05)$. Maka dapat diartikan bahwa dukungan sosial keluarga berpengaruh positif dan signifikan terhadap pengembangan karir. Arah koefisien regresi yang positif sebesar 0,421 . Dengan demikian, hipotesis keempat dinyatakan diterima yaitu ada pengaruh signifikan antara dukungan sosial keluarga terhadap pengembangan karir.

\section{Pengaruh Konflik Peran Ganda Terhadap Pengembangan Karir}

Hasil pengujian yang dilakukan hipotesis kelima yaitu variabel konflik peran ganda terhadap pengembangan karir menghasilkan nilai $t$ hitung sebesar 0,216 dengan nilai signifikansi sebesar $0,829(p<$ 0,05 ). Maka dapat diartikan bahwa konflik peran ganda berpengaruh positif dan tidak signifikan terhadap pengembangan karir. Arah koefisien regresi yang positif sebesar 0,023 . Dengan demikian, hipotesis kelima dinyatakan ditolak yaitu tidak ada pengaruh signifikan antara konflik peran ganda terhadap pengembangan karir.

\section{SIMPULAN}

Motivasi kerja tidak berpengaruh terhadap konflik peran ganda, karena konflik peran ganda dapat teratasi jadi motivasi kerja tidak berpengaruh terhadap konflik peran ganda.

Dukungan sosial keluarga tidak berpengaruh pada konflik peran ganda, karena konflik peran ganda dapat teratasi jadi dukungan sosial keluarga tidak berpengaruh terhadap konflik peran ganda.

Sedangkan motivasi kerja berpengaruh terhadap pengembangan karir artinya semakin tinggi motivasi kerja dari dosen wanita, maka dapat meningkatkan dan lebih mengembangkan karirnya menuju yang 
lebih bagus. Dukungan sosial keluarga berpengaruh terhadap pengembangan karir. Artinya dukungan yang diberikan oleh keluarga terutama dari suami sangat kuat seperti memberikan bantuan langsung, saran dan dorongan untuk maju, sehingga dosen wanita merasa terbantu dan terdukung dalam karirnya.

Konflik peran ganda tidak berpengaruh terhadap pengembangan karir. Karena meskipun konflik peran ganda teratasi, tetapi ada sebagian dosen wanita yang tidak tertarik pada pengembangan karir, jadi konflik peran ganda tidak berpengaruh pada pengembangan karir.

Untuk meningkatkan motivasi kerja khususnya pada indikator kebutuhan afiliasi yaitumengenai pencapaian suatu karya yang lebih baik pada dosen wanita belum begitu optimal, sebaiknya perlu ditingkatkan agar dapat mencapai pengembangan karir yang lebih bagus.

Untuk meningkatkan dukungan sosial khususnya pada indikator dukungan instrumental yaitu bantuan langsung dari suami, sebaiknya dosen wanita lebih terbuka dan tidak segan untuk meminta bantuan langsung kepada suami untuk saling berbagi tugas rumah tangga. Sedangkan peran dukungan sosial keluarga dari suami didalam organisasi, yaitu memberikan dukungan moral dan emosional seperti perhatian terhadap karir pekerjaan istrinya diorganisasi. Sedangkan peran organisasi adalah membuat acara gathering atau kebersamaan yang melibatkan suami sehingga suami memahami kegiatan istri di dalam organisasi.

Penelitian ini mencakup permasalahan dosen wanita dalam pengembangan karir yang terjadi didalam organisasi maupun didalam rumah tangga, dan masih perlu diteliti lebih dalam karena penelitian ini hanya menggunakan pengukuran pengembangan karir yang bersifat umum, maka penelitian ini kurang optimal.

Penelitian ini hanya menggunakan pengukuran pengembangan karir yang bersifat umum, untuk penelitian yang akan datang diharapkan dapat menggunakan pengukuran kinerja yang bersifat khusus pada dosen wanita.

\section{DAFTAR PUSTAKA}

Anggriana, T, M. Margawati, M, T. \& Wardani, Y, S. (2013). Konflik Peran Ganda Pada Dosen Perempuan Ditinjau Dari Dukungan Sosial Keluarga. Rangkuman Skripsi. IKIP PGRI Madiun Fakultas IImu Pendidikan.

Anoraga, P. (2005). Psikologi Kerja. Jakarta: PT. Rineka Cipta.

Hamid. (2005). Hubungan Antara Androginitas Dengan Konflik Peran Ganda Pada Wanita. Jurnal Intelektual. 3, 2. 2005.

Handayani, S, C. dan Novianto, A. (2004). Kuasa Wanita Jawa, Yogyakarta: LKIS, 2004, hlm. 42.

Handoko, H. (2008). Manajemen Personalia \& Sumber daya Manusia. Yogyakarta: BPFE.

Haryani, Y, P. (2013). Korelasi Antara Pengembangan Karir Dengan Motivasi Kerja Dan Keinginan Untuk Pensiun. Skripsi. Fakultas Ekonomi Universitas Udayana. Jurnal Buletin Studi Ekonomi, 18 (2).

Munandar, C, U. (2001). Wanita Karir: Tantangan dan Peluang. Wanita Dalam Masyarakat Indonesia. Yogyakarta: Sunan Kalijaga Press.

Nugroho, S, T. (2009). Pengaruh Pola Kepemimpinan, Motivasi, dan Pengembangan Karir Terhadap Kinerja Karyawan. Skripsi. Universitas Muhammadiyah Surakarta. http://etd. eprints.ums.ac.id/3060/1/B200050003.pdf. 
Mustikallah, O. (2013). Hubungan Antara Dukungan Sosial Keluarga Dengan Motivasi Kesembuhan Pasien Napza Di Rumah Sakit Ketergantungan Obat Jakarta Timur. Jurnal ilmiah kesehatan, 5 (3).

Rustiana, E, R. (2006). Dukungan Sosial dan Pengaruhnya Bagi Kesehatan. Jurnal KESMAS, $1(1)$.

Saman, A. \& Dewi, P, M, E. (2012). Pengaruh Motivasi Kerja dan Dukungan Suami Terhadap Stress Konflik Peran Ganda dan Kepuasan Perkawinan Pada Wanita Karir. Jurnal Psikologi: Teori\& Terapan, 2 (2).

Samsuddin, Sadili. (2005). Manajemen Sumber Daya Manusia. Bandung: CV. Pustaka Setia.

Setyowati, R \& Riyono, B. (2003). Perbedaan Aspirasi Karir Antara Wanita Yang Sudah Menikah dan Belum Menikah Pada Pegawai Negeri Sipil. Psikologika: Jurnal Pemikiran \& Penelitian Psikologi. 16 (7).

Ummu, H. (2011). Stress Kerja Ditinjau Dari Konflik Peran Ganda dan Dukungan Sosial Pada Perawat. Jurnal Psikologi. Universitas Widya Dharma Klaten. 8 (1). 